\title{
Descriptive Representatives, Party Status, and Latino Representation in Congressional Legislation
}

\author{
Walter Clark Wilson
}

Empirical research has yet to adequately address the substantive implications of Latino descriptive representation in legislative activities like bill sponsorship, or to explore whether party status impacts the relationship between descriptive and substantive representation. I examine an original dataset of bills sponsored during the 109th and 110th congresses to assess the effect of descriptive representation on the sponsorship of Latino interest bills. Results illustrate that Latino representatives sponsored more Latino interest bills than their non-Latino colleagues during both congresses. The heightened commitment of Latino representatives to the sponsorship of Latino interest bills was unaffected by important partisan changes during the period in question, underscoring the substantive effect of descriptive representation.

Do Latino U.S. Representatives sponsor more bills that represent Latino interests than their non-Latino colleagues? Does party status affect the relationship between descriptive representation and the substantive representation? Empirical research has yet to adequately address these questions. Studies suggest that female and African American members of Congress sponsor more legislation representing female and black interests, respectively (Canon 1999; Swers 2002). Minority representatives appear to increase their overall sponsorship activities during Democratically controlled congresses (Rocca and Sanchez 2008). Evidence suggests that female representatives increase their sponsorship of social welfare bills when they are in the majority (Swers 2002, 49). In this article, I explore the relationship of descriptive representation to the sponsorship of Latino interest bills during the 109th and 110th congresses, and examine whether changes in party status due to the recent change of partisan control in the U.S. House of Representatives impact this relationship.

The literature relating descriptive representation to substantive representation is well known to scholars interested in the representation of politically disadvantaged groups like women, African Americans, and Latinos. Descriptive representation, typically conceptualized as the presence of an important shared physical trait like sex, race or ethnicity between groups of constituents and elected officials, is often theorized to enhance the substantive representation of female, African American or Latino constituencies (Pitkin 1967; Mansbridge 1999; Williams 1998). A number of empirical

WALTER CLARK WILSON is an assistant professor of political science at the University of Texas at San Antonio.

The American Review of Politics, Vol. 32, Spring, 2011: 57-76

(c)2011 The American Review of Politics 
studies suggest that female (Swers 2002; Wolbrecht 2002), African American (Canon 1999; Lublin 1997), and Latino (Huerta and Santos 2006; Kerr and Miller 1997; Lublin 1997; Wilson 2009) representatives are "on average ... more likely to represent the concerns and interests of citizens from those groups" (Williams 1998, 6).

While numerous studies demonstrate consequential differences in the representative behaviors of male and female, black and white, and Latino and non-Latino representatives, these literatures pay inadequate attention to the influence of partisan contexts. For example, one might expect partisan context to significantly shape representative behavior with respect to activities like bill sponsorship, where success may often rest on majority party status (Frantzitch 1979; Moore and Thomas 1990; Swers 2002). Particularly in an era of increasingly cohesive congressional parties (Theriault 2008), it is important to ask whether party status significantly impacts the efforts of descriptive representatives to substantively represent disadvantaged groups like Latinos. With respect to Latino representation, research also seldom examines substantive contributions to the legislative process. In other words, the Latino representation literature contains few studies of behaviors that can affect the scope and content of the congressional agenda- a critical shortcoming if we desire to fully understand the implications of descriptive representation to the substantive representation of Latinos. This study addresses each of these shortcomings by examining the sponsorship of Latino interest bills in changing partisan contexts. The results of this analysis clarify qualities of legislative representation that differentiate Latino and non-Latino representatives, shed light on whether party status impacts the relationship between descriptive and substantive representation, and strengthens evidence that descriptive representation influences substantive representation.

\section{Descriptive Representatives, Bill Sponsorship, and Majority Party Status}

Bill sponsorship is clearly related to policy responsiveness, but researchers have yet to adequately explore the behavior as an indicator of Latino representation. At the congressional level, most analyses of Latino representation focus on voting patterns using the familiar model of preference congruence to indicate policy responsiveness (Miller and Stokes 1963; Eulau and Karps 1977). With mixed results, scholars have examined whether Latino representatives vote more liberally than their non-Latino colleagues (Welch and Hibbing 1984; Casellas 2007) and also whether Latino representatives are more supportive of Latino interests during roll call votes (Hero and Tolbert 1995; Kerr and Miller 1997; Santos and Huerta 2001; Huerta and Santos 2006; Knoll 2009). 
At the local level, an important literature examines the impact of Latino representatives on school boards and among school administrators on Latino student performance. Generally, Latino descriptive, or passive representation in these circumstances appears associated with better educational outcomes for Latino students (Meier 1993; Ross et al. 2010). While existing literatures on Latino representation provides important insights, they do not assess qualities of contributions to policymaking, or whether party status affects the responsiveness of Latino representatives to Latino constituencies. The following analysis of Latino representation in congressional bill sponsorship behaviors addresses these lacunae in the literature.

Much as position taking in behaviors like roll call voting can be used to measure congruence with constituency preferences or support for constituency interests, and therefore policy responsiveness, bill sponsorship can be evaluated with respect to the positions legislators take that represent interests of their constituents. This observation has not been lost on scholars examining the relationship between descriptive representation and substantive representation. As an activity with high "attitudinal and resource demands" (Tamerius 1995, 104), and which can indicate a representative's commitment to bringing group issues to the policy agenda (Swers 2002, 34), bill sponsorship is a behavior that reveals the policy preferences and priorities of representatives (Hall 1996).

Literature on the representation of both women and African Americans at the Congressional level includes studies that assess the effect of descriptive representation on the substantive representation of these groups by delving into the content of the bills representatives sponsor. An important example of this research is Swers's (2002) analysis of the relationship between descriptive representation and the sponsorship of women's issue bills in Congress. Swers found that female representatives of both parties generally sponsored larger numbers of "feminist" and "social welfare" bills than their male colleagues during congresses controlled by both Democrats and Republicans (2002, 44-45). Swers' study also illustrates that partisans of both sexes sponsored more women's issue bills when their party was in the majority (38-39). Canon (1999) conducted a similar study that examined the sponsorship of legislation with "racial content" during the Democratically controlled 103rd Congress. Black representatives he termed "commonality members," as well as older black representatives, sponsored more bills with "racial" content than white representatives, further supporting the notion that descriptive representation impacts substantive representation in sponsorship behaviors $(1999,196)$.

The literature on Latino representation addresses questions about whether Latino representatives are more active sponsors of bills that represent Latinos at state legislative level, but not the congressional level. 
Bratton's (2006) study of Latino representation during 2001 in seven state legislatures revealed that, while Latino representatives did not differ significantly from their partisan counterparts in terms of their sponsorship of education, health or welfare related bills, they did sponsor a significantly larger number of "Latino Interest" bills than non-Latinos. At the congressional level, previous studies of Latino representation in bill sponsorship rely on measures of sponsorship productivity rather than legislative content in order to assess the impact of Latino descriptive representation on sponsorship patterns. Research by Santos and Huerta (2001) revealed no significant differences between Latino and non-Latino representatives with regard to numbers of bills they sponsored or the numbers of public laws they authored. Rocca and Sanchez (2008), however, discovered that Latino representatives sponsored significantly fewer pieces of legislation than did non-Latinos. Their study, which assessed sponsorship patterns across congresses controlled by both Democrats and Republicans, also revealed that Latino representatives (and African American representatives) sponsored more legislation during Democratically controlled congresses (Rocca and Sanchez 2008).

Whether party status impacts sponsorship of specific subsets of bills by descriptive representatives, like those linked to specific constituencies (Latinos, for example), remains an open question. A number of studies suggest that majority party status increases the sponsorship activities of representatives (Frantzitch 1979; Moore and Thomas 1990; Swers 2002; Rocca and Sanchez 2008). Such a phenomenon is to be expected, according to Swers, because "majority party status translates into agenda control and responsibility" (2002, 39). Because of the greater influence rank-and-file members of the majority have with influential gate-keepers like party leaders and committee chairs, Swers argues that "representatives increase their sponsorship rates when the believe they have an opportunity to shape policy outcomes and to see their proposals enacted into law" $(2002,39)$.

The question of whether party status impacts the relationship between descriptive and substantive representation is particularly interesting given the centrality of shared experiences between descriptive representatives and constituencies to expectations of an empirical relationship between descriptive and substantive representation (Mansbridge 1999; Williams 1998). Theorists argue that descriptive representatives who are "existentially close to the issues" affecting groups like women, African Americans, or Latinos by virtue of the life experiences they share with those populations, possess advantages in terms of their abilities to recognize, understand, and articulate the interests, concerns, and perspectives of such constituencies (Mansbridge 1999). The theoretical literature on descriptive representation provides little reason to expect party status to intervene on its substantive effects. Scholars 
framing the substantive importance of descriptive representation in terms of the representation of perspectives, and the ability of descriptive representatives to articulate "uncrystallized" group interests in processes of deliberation, deemphasize the attachment of such activities to traditional forms of legislative accountability (Mansbridge 1999, 635). Rather than party, electoral, or other concerns informing the relationship between descriptive and substantive representation, theorists articulate a much more relational logic, whereby descriptive representatives approach issues from internalized social perspectives that establish stating points for reasoning, rather than determine the content of conclusions or specific actions (Young 2000, 136). Under such a conceptualization, the relationship between descriptive and substantive representation appears independent of traditional mechanisms of accountability, and we might expect a heightened commitment to the needs of group constituencies from descriptive representatives regardless of partisan context. Given that descriptive representation appears theoretically tied to starting points for policy discussion and deliberation, we might also expect it to influence agenda setting behaviors like bill sponsorship substantially.

An alternative possibility, which would indicate that the effect of descriptive representation is contextual, is that descriptive representatives might increase their sponsorship of group interest bills when they are in the majority due to enhanced influence with leaders and committee chairs. Along similar lines, we might expect minority status to depress the efforts of descriptive representatives to sponsor bills designed to address group interests because minority party status diminishes representatives' influence, making such efforts less likely to succeed. Such findings would indicate that the relationship between descriptive and substantive representation is contingent upon party status or institutional position, and that the likelihood descriptive representatives act on behalf of their group constituencies depends on their opportunities to produce results.

As a behavioral indicator of representation, bill sponsorship straddles a theoretical divide between expectations based on traditional mechanisms of representative accountability like party and reelection, and expectations that shared experiences and perspectives between representatives and groups lead to greater action on behalf of groups by representatives. Clearly, the likelihood of legislative success must condition a significant amount of representatives' sponsorship behaviors. But bill sponsorship also stands out as an important way for representatives to articulate problems and policy solutions. If descriptive representatives possess heightened commitments to expressing the interests, concerns, and perspectives of the groups in which they are members, it seems plausible that these efforts are exerted independent of party effects. By addressing the relationship of descriptive represen- 
tation to sponsorship of Latino interest bills in Congress, and the effect of majority party status on this relationship, the following analysis moves literature on Latino representation in directions that refine our understandings of the contextual and qualitative importance of descriptive representation.

\section{Data}

In order to examine whether Latino members of Congress differ from their non-Latino counterparts in terms of the Latino interest content of the bills they sponsor, and to assess the effects of party status on these sponsorship patterns, I considered 9300 public bills sponsored during the Republican controlled 109th Congress (2005-2006) and 10420 public bills sponsored during the Democratically controlled 110th Congress (2007-2008). From this population of bills, I identified and coded all Latino interest bills. Latino interest bills contain measures that "might decrease discrimination against Latinos or alleviate the effects of that discrimination, or [that] were designed to improve the socioeconomic status or health of Latinos" (Bratton 2006, 1142). I also considered symbolic bills that addressed Latino cultural or societal concerns, or paid tribute to important Latino leaders to be Latino interest bills because of the function such bills serve in fostering greater inclusion and recognition of Latino concerns in American society. Among bills sponsored during the 109th Congress, I identified 241 Latino interest bills, 80 of which (one-third) were sponsored by Latino representatives. Among 110th Congress bills, I identified 218 Latino interest bills, 83 of which $(38 \%)$ were sponsored by Latino representatives. The inclusive definition of Latino interest legislation used for this research resulted in the analysis of bills that address diverse issues and policies. Table 1 illustrates the distribution of issues within the set of Latino interest bills examined.

Latino interests in congressional legislation appeared both explicitly, calling for actions that impact specific Latino and Hispanic populations directly, and implicitly, in proposals tied to disproportionate concerns of Latinos in certain areas of public policy. A few examples help to illustrate the presence of Latino interests in bills examined by this analysis. The Latino interests in HR 512, sponsored by Representative Xavier Becerra (DCA) during the 110th Congress, are quite explicit. The bill would establish a "Commission to Study the Potential Creation of the National Museum of the American Latino." Latino interests are also clear in HR 468, sponsored by Representative Hilda Solis (D-CA) during the 110th Congress, which would "make grants to carry out activities to prevent teen pregnancy in racial or ethnic minority or immigrant communities." Implicit Latino interests in many linguistic education and immigration-related issues make HR 2957, 
Table 1. Issues in Latino Interest Bills, 109th and 110th Congresses

\begin{tabular}{lccr}
\hline Issue & 109th Congress & 110th Congress & Total \\
\hline Immigration & $79(12)$ & $31(11)$ & $110(23)$ \\
Health & $31(14)$ & $57(17)$ & $88(31)$ \\
Symbolic & $48(20)$ & $40(22)$ & $88(42)$ \\
Civil Rights/Equal Opportunity & $23(7)$ & $39(9)$ & $62(16)$ \\
Education & $19(8)$ & $27(9)$ & $46(17)$ \\
Foreign Affairs & $16(7)$ & $6(4)$ & $22(11)$ \\
Other Issues & $25(12)$ & $17(11)$ & $42(23)$ \\
Total & $241(80)$ & $217(83)$ & $458(163)$ \\
Note: Number of bills sponsored by Latino representatives in parentheses. & \\
\hline
\end{tabular}

"To amend the Elementary and Secondary Education Act of 1965 to improve educational practices for limited English proficient students and immigrant students" sponsored by Representative Joe Baca (D-CA) during the 110th Congress, a Latino interest bill. Large numbers of recent Latino immigrants similarly make implicit Latino interests evident in HR 427, sponsored by Representative Edolphous Towns (D-NY) during the 110th Congress, which would "assure coverage for legal immigrant children and pregnant women under the Medicaid Program and the State children's health insurance program." And a diversity of social problems accompanying the exploding Latino population in the Mexican border region makes HR 2068, sponsored by Representative Sylvestre Reyes (D-TX) during the 110th Congress, a Latino interest bill. The bill proposes a Southwest Regional Border Authority to address the many educational, economic, and infrastructural challenges faced by growing immigrant communities.

In addition to bills that address issues substantively, or programmatically, I also consider a number of symbolic bills because of the importance of such legislation to raising Latino concerns, incorporating Latino traditions and figures into American culture, and articulating "uncrystallized" Latino interests (Mansbridge 1999). House Concurrent Resolution 426, sponsored by Representative Maxine Waters (D-CA) during the 110th Congress, which recognizes the 10th anniversary of, work done by, and challenges faced by, the Minority AIDS Initiative, publicizes the disproportionate health threat HIV and AIDS pose to Latinos and other minority communities. H Res 347, sponsored by Representative Joe Baca (D-CA) during the 110th congress, recognizes the significance of Cinco de Mayo, and serves to incorporate this Mexican holiday into American culture. While it is arguable that symbolic bills do not "do" anything substantive for Latinos, such legislation clearly helps to give Latinos "voice" in the legislative process 
(Williams 1998). Both substantive and symbolic Latino interest bills, then, constitute legislative efforts that "act for" Latinos as a constituency, and provide substantive representation (Pitkin 1967).

\section{Dependent Variables}

I created four separate dependent variables for the following analysis of Latino representation in bill sponsorship, each of which assesses sponsorship behavior at the member-level of analysis. The first is the Total Bills Sponsored by representatives per congress. This analysis establishes the dynamics related to overall patterns of bill sponsorship in the data examined here. Second, I considered sponsorship of Latino Interest Bills. This dependent variable equaled the total number of Latino interest bills sponsored by individual representatives per congress. Finally, I divided Latino interest bills into subcategories to create two additional dependent variables: Substantive Latino Interest bills and Symbolic Latino Interest bills. Examining sponsorship of these types of bills helps to refine my analysis of the influence of descriptive representation on Latino interest bill sponsorship and address potential concerns related to the conflation of these types of legislation in relation to the concept of substantive representation.

\section{Independent Variables}

My analyses of Latino representation in congressional bill sponsorship consider a number of independent variables. Most important is whether the bill sponsor is a Latino representative. ${ }^{1}$ This dummy indicator captures the effect of descriptive representation on sponsorship patterns. Based on differences in experiences and political perspectives that theoretically set members of disadvantaged groups apart from more privileged groups, and descriptive representatives apart from their colleagues (Mansbridge 1999; Williams 1998), I would expect Latino representatives to be more active sponsors of Latino interest bills than their non-Latino colleagues.

A second critical independent variable is the Latino population proportion $^{2}$ of districts represented by bill sponsors. Given well-established electoral connections reflected by policy responsiveness on the part of representatives, the importance of this variable to analyses of Latino representation in bill sponsorship is obvious (Mayhew 1974; Miller and Stokes 1963; Eulau and Karps 1977). I would expect representatives with larger Latino constituencies to sponsor more Latino interest bills.

Two additional variables of heightened importance tap the effect of party status and appear in a set of models that examine sponsorship patterns of representatives who served complete terms in both the 109th and 110th 
congresses. The first of these is a dummy indicator that captures the effect of Majority Party Status on sponsorship patterns for all representatives examined. I would expect majority party status to increase the overall sponsorship activities of Latino and non-Latino representatives (Franztich 1979; Moore and Thomas 1991; Rocca and Sanchez 2008).

A second variable assesses the effect of majority party status on the sponsorship patterns of Latino representatives specifically. To capture this effect I created a variable which interacts ethnicity with party status by multiplying Latino representative by Majority Party to create Latino*Majority. Rocca and Sanchez (2008) suggest that marginalization within a majority white institution depresses overall sponsorship by Latino representatives, especially during Republican controlled congresses when most of these members are in the minority. This analysis explores whether minority party status similarly depresses the sponsorship of Latino interest bills by Latino representatives, therefore impacting the relationship between descriptive representation and the substantive representation of Latinos. In essence, this variable assesses the relative resilience of descriptive representation as a factor affecting the substantive representation of Latinos in congressional legislation.

I modeled a number of control variables in each of the following analyses. I control for political party $(1=$ Democrat, $0=$ Republican $)$ and Member Conservatism ${ }^{3}$ because Democrats and more liberal representatives may be more supportive of Latino interests (Hero and Tolbert 1995; Bratton 2006; Knoll 2009; Wilson 2009). In models of Latino interest bills and AntiLatino Interest bills, I control for the Total Bills Sponsored because I expect more active bill sponsors to sponsor more legislation in subcategories of bills (Swers 2002). I control for whether a sponsor is a Female Representative or Minority Representative (African American or Asian American) because some studies suggest that minority representatives are more supportive of Latino interests than white representatives (Huerta and Santos 2006; Bratton 2006).

The following analyses also model a number of constituency-level control variables. I control for the Black Population in congressional districts because historical experiences with social and political marginalization give blacks and Latinos overlapping interests in a number of issue areas addressed by Latino interest bills. I control for Constituency Conservatism ${ }^{4}$ because of the importance of constituency policy preferences to dyadic models of policy responsiveness (Miller and Stokes 1963; Eulau and Karps 1977). Finally, I control for Border State District to indicate whether representatives' districts are in states that border Mexico. This variable taps regional effects related to heightened interests in immigration issues along the border. 


\section{Methodology}

My examination of Latino representation in bill sponsorship considers sponsorship patterns of representatives during the 109th and 110th congresses separately, and in a combined assessment of the sponsorship patterns of all representatives that served full terms in both of these congresses. My approach is therefore able to assess the effect of descriptive representation on the sponsorship of Latino interest bills in two different partisan contexts, and to assess the effect that changes in majority party status have on the sponsorship patterns of individual representatives. I used negative binomial regression ${ }^{5}$ models to estimate the numbers of bills sponsored in each bill category (Total Bills Sponsored, Latino Interest Bills, Substantive Latino Interest bills and Symbolic Latino Interest bills) in each of the following analyses. Observations in the third set of models, which assess the effect of changes in party status on sponsorship patterns, are clustered on the 368 representatives that served full terms in both the 109th and 110th Congresses in recognition of the likelihood that multiple observations of the same representative's sponsorship patterns are not independent (Long and Freese 2003).

\section{Results}

Results of my analyses of Latino representation in sponsorships during the 109th and 110th Congresses appear in Tables 2 and 3. Consistent with Rocca and Sanchez (2008), I found that average Latino representatives sponsored significantly fewer bills, overall, than non-Latino representatives during both congresses. Given a district population that was 50 percent Latino (a vast majority Latino representatives in both congresses served larger Latino constituencies) and holding other variables at their means, Latino representatives were estimated to sponsor approximately 16 bills during the 109th Congress and 18 bills during the 110th Congress. Similarly situated non-Latino representatives (the vast majority represented smaller Latino constituencies) were estimated to sponsor approximately 26 bills during the 109th Congress and 27 bills during the 110th Congress.

While Latino representatives were less active legislators overall than non-Latino representatives, they still sponsored, on average, significantly more Latino interest bills than their non-Latino colleagues during both Congresses. The relationship between descriptive representation and Latino interest bill sponsorship appears to have been stronger during the 110th Congress than during the 109th Congress. During the 110th Congress, Latino representatives sponsored significantly more Latino interest bills, as well as significantly more Substantive and Symbolic Latino interest bills 
Table 2. Bill Sponsorship Patterns, 109th Congress
Negative Binomial Regression, Counts of Bills

\begin{tabular}{|c|c|c|c|c|}
\hline & $\begin{array}{c}\text { Total } \\
\text { Bills } \\
\text { Sponsored }\end{array}$ & $\begin{array}{l}\text { Latino } \\
\text { Interest } \\
\text { Bills }\end{array}$ & $\begin{array}{c}\text { Substantive } \\
\text { Latino } \\
\text { Interest }\end{array}$ & $\begin{array}{l}\text { Symbolic } \\
\text { Latino } \\
\text { Interest }\end{array}$ \\
\hline Latino Representative & $\begin{array}{l}-0.481^{* * *} \\
(0.187)\end{array}$ & $\begin{array}{c}0.716^{*} \\
(0.391)\end{array}$ & $\begin{array}{c}0.630 \\
(0.433)\end{array}$ & $\begin{array}{c}0.730 \\
(0.668)\end{array}$ \\
\hline Democrat & $\begin{array}{l}-0.232 \\
(0.181)\end{array}$ & $\begin{array}{c}0.254 \\
(0.562)\end{array}$ & $\begin{array}{c}0.327 \\
(0.602)\end{array}$ & $\begin{array}{c}0.272 \\
(1.286)\end{array}$ \\
\hline Member Conservatism & $\begin{array}{c}0.230 \\
(0.209)\end{array}$ & $\begin{array}{l}-0.077 \\
(0.621)\end{array}$ & $\begin{array}{l}-0.066 \\
(0.659)\end{array}$ & $\begin{array}{c}0.204 \\
(1.476)\end{array}$ \\
\hline Total Bills Sponsored & - & $\begin{array}{l}0.029 * * * \\
(0.005)\end{array}$ & $\begin{array}{l}0.031^{* * * *} \\
(0.005)\end{array}$ & $\begin{array}{c}0.011 \\
(0.011)\end{array}$ \\
\hline Female Representative & $\begin{array}{c}0.122 \\
(0.088)\end{array}$ & $\begin{array}{l}-0.071 \\
(0.231)\end{array}$ & $\begin{array}{l}-0.164 \\
(0.253)\end{array}$ & $\begin{array}{c}0.143 \\
(0.461)\end{array}$ \\
\hline Minority Representative & $\begin{array}{c}0.110 \\
(0.158)\end{array}$ & $\begin{array}{c}0.501 \\
(0.440)\end{array}$ & $\begin{array}{c}0.431 \\
(0.473)\end{array}$ & $\begin{array}{c}0.506 \\
(0.943)\end{array}$ \\
\hline Latino Population & $\begin{array}{c}0.005 \\
(0.004)\end{array}$ & $\begin{array}{l}0.033^{* * *} \\
(0.008)\end{array}$ & $\begin{array}{l}0.029^{* * * *} \\
(0.009)\end{array}$ & $\begin{array}{l}0.057 * * * \\
(0.015)\end{array}$ \\
\hline Black Population & $\begin{array}{l}-0.008 \\
(0.003)\end{array}$ & $\begin{array}{c}0.006 \\
(0.010)\end{array}$ & $\begin{array}{c}0.005 \\
(0.011)\end{array}$ & $\begin{array}{c}0.019 \\
(0.023)\end{array}$ \\
\hline Constituency Conservatism & $\begin{array}{l}-0.018^{* * *} \\
(0.004)\end{array}$ & $\begin{array}{l}-0.018 \\
(0.011)\end{array}$ & $\begin{array}{l}-0.024 * \\
(0.012)\end{array}$ & $\begin{array}{c}0.003 \\
(0.024)\end{array}$ \\
\hline Border State & $\begin{array}{l}-0.014 \\
(0.102)\end{array}$ & $\begin{array}{c}0.248 \\
(0.266)\end{array}$ & $\begin{array}{c}0.256 \\
(0.294)\end{array}$ & $\begin{array}{c}0.142 \\
(0.510)\end{array}$ \\
\hline Constant & $\begin{array}{l}4.040^{* * *} \\
(0.236)\end{array}$ & $\begin{array}{l}-1.877 * * * \\
(0.663)\end{array}$ & $\begin{array}{l}-1.778 * * \\
(0.705)\end{array}$ & $\begin{array}{l}-4.999 * * * \\
(1.485)\end{array}$ \\
\hline lnalpha & $\begin{array}{l}-1.020 \\
(0.074)\end{array}$ & $\begin{array}{l}-0.645 \\
(0.381)\end{array}$ & $\begin{array}{l}-0.579 \\
(0.391)\end{array}$ & $\begin{array}{l}-0.289 \\
(0.696)\end{array}$ \\
\hline alpha & $\begin{array}{c}0.361 \\
(0.027)\end{array}$ & $\begin{array}{c}0.525 \\
(0.200)\end{array}$ & $\begin{array}{c}0.561 \\
(0.219)\end{array}$ & $\begin{array}{c}0.749 \\
(0.521)\end{array}$ \\
\hline Number of Observations & 438 & 438 & 438 & 438 \\
\hline Likelihood Ratio Chi-Square & 38.730 & 171.330 & 153.27 & 77.96 \\
\hline Probability $>$ Chi-Square & 0.000 & 0.000 & 0 & 0 \\
\hline Pseudo R-Square & 0.011 & 0.217 & 0.2166 & 0.2761 \\
\hline
\end{tabular}


Table 3. Bill Sponsorship Patterns, 110th Congress
Negative Binomial Regression, Counts of Bills

\begin{tabular}{|c|c|c|c|c|}
\hline & $\begin{array}{c}\text { Total } \\
\text { Bills } \\
\text { Sponsored }\end{array}$ & $\begin{array}{c}\text { Latino } \\
\text { Interest } \\
\text { Bills }\end{array}$ & $\begin{array}{c}\text { Substantive } \\
\text { Latino } \\
\text { Interest }\end{array}$ & $\begin{array}{l}\text { Symbolic } \\
\text { Latino } \\
\text { Interest }\end{array}$ \\
\hline Latino Representative & $\begin{array}{l}-0.397 * \\
(0.188)\end{array}$ & $\begin{array}{l}1.159^{* * * *} \\
(0.436)\end{array}$ & $\begin{array}{c}0.868 * \\
(0.502)\end{array}$ & $\begin{array}{l}2.493 * * * \\
(0.825)\end{array}$ \\
\hline Democrat & $\begin{array}{c}0.250 \\
(0.194)\end{array}$ & $\begin{array}{c}0.148 \\
(0.842)\end{array}$ & $\begin{array}{c}0.366 \\
(0.896)\end{array}$ & $\begin{array}{l}-3.211 \\
(2.335)\end{array}$ \\
\hline Member Conservatism & $\begin{array}{c}0.178 \\
(0.219)\end{array}$ & $\begin{array}{l}-0.632 \\
(0.920)\end{array}$ & $\begin{array}{l}-0.454 \\
(0.987)\end{array}$ & $\begin{array}{l}-3.052 \\
(2.342)\end{array}$ \\
\hline Total Bills Sponsored & - & $\begin{array}{l}0.024^{* * *} \\
(0.006)\end{array}$ & $\begin{array}{l}0.022 * * * \\
(0.007)\end{array}$ & $\begin{array}{l}0.043 * * * \\
(0.014)\end{array}$ \\
\hline Female Representative & $\begin{array}{c}0.093 \\
(0.078)\end{array}$ & $\begin{array}{c}0.085 \\
(0.239)\end{array}$ & $\begin{array}{c}0.157 \\
(0.258)\end{array}$ & $\begin{array}{l}-1.007 \\
(0.625)\end{array}$ \\
\hline Minority Representative & $\begin{array}{c}0.101 \\
(0.141)\end{array}$ & $\begin{array}{c}0.122 \\
(0.417)\end{array}$ & $\begin{array}{c}0.040 \\
(0.451)\end{array}$ & $\begin{array}{c}1.613 \\
(1.096)\end{array}$ \\
\hline Latino Population & $\begin{array}{c}0.441 \\
(0.355)\end{array}$ & $\begin{array}{l}2.507 * * * \\
(0.876)\end{array}$ & $\begin{array}{l}2.635^{* * * *} \\
(1.001)\end{array}$ & $\begin{array}{c}3.274 * \\
(1.763)\end{array}$ \\
\hline Black Population & $\begin{array}{l}-0.702 * * \\
(0.292)\end{array}$ & $\begin{array}{c}1.668 * \\
(0.983)\end{array}$ & $\begin{array}{c}1.741^{*} \\
(1.057)\end{array}$ & $\begin{array}{l}-2.364 \\
(3.138)\end{array}$ \\
\hline Constituency Conservatism & $\begin{array}{l}-0.013^{* * *} \\
(0.004)\end{array}$ & $\begin{array}{l}-0.020^{*} \\
(0.012)\end{array}$ & $\begin{array}{l}-0.019 \\
(0.013)\end{array}$ & $\begin{array}{l}-0.043 \\
(0.030)\end{array}$ \\
\hline Border State & $\begin{array}{c}0.032 \\
(0.097)\end{array}$ & $\begin{array}{c}0.452 \\
(0.300)\end{array}$ & $\begin{array}{c}0.218 \\
(0.341)\end{array}$ & $\begin{array}{l}2.103 * * * \\
(0.711)\end{array}$ \\
\hline Constant & $\begin{array}{l}3.650^{* * *} \\
(0.210)\end{array}$ & $\begin{array}{l}-2.082 * * * \\
(0.763)\end{array}$ & $\begin{array}{l}-2.229^{* * *} \\
(0.827)\end{array}$ & $\begin{array}{l}-3.102 * \\
(1.846)\end{array}$ \\
\hline lnalpha & $\begin{array}{l}-1.185 \\
(0.075)\end{array}$ & $\begin{array}{l}-0.409 \\
(0.340)\end{array}$ & $\begin{array}{l}-0.092 \\
(0.336)\end{array}$ & $\begin{array}{l}-0.268 \\
(0.634)\end{array}$ \\
\hline alpha & $\begin{array}{c}0.306 \\
(0.023)\end{array}$ & $\begin{array}{c}0.664 \\
(0.226)\end{array}$ & $\begin{array}{c}0.912 \\
(0.307)\end{array}$ & $\begin{array}{c}0.765 \\
(0.485)\end{array}$ \\
\hline Number of Observations & 443 & 443 & 443 & 443 \\
\hline Likelihood Ratio Chi-Square & 62.140 & 172.29 & 134.33 & 104.42 \\
\hline Probability $>$ Chi-Square & 0.000 & 0 & 0 & 0 \\
\hline Pseudo R-Square & 0.018 & 0.2364 & 0.2025 & 0.4595 \\
\hline
\end{tabular}


than their non-Latino colleagues. During the 109th Congress, the effect of descriptive representation on sponsorship patterns was only present when substantive and symbolic Latino interest bills were considered together as a single category of Latino interest bills. Combined, these analyses suggest both that descriptive representation influenced the sponsorship of Latino interest bills, and that these effects applied to the sponsorship of both substantive and symbolic forms of Latino interest legislation. Importantly, then, the impact of descriptive representation on Latino interest bill sponsorship did not appear disproportionately shaped by either symbolic or substantive legislation, but rather reflected greater efforts to both voice Latino cultural concerns and priorities, and to place Latino interest policy proposals on the agenda.

Latino population also shared a positive and strongly significant relationship with the sponsorship of Latino interest bills during both Congresses, suggesting that Latino and non-Latino representatives of both parties respond to larger Latino constituencies with greater efforts to represent them in their sponsorship behaviors. Constituency conservatism shared a weak negative relationship with Latino interest bill sponsorship during both Congresses, and sponsorship productivity, measured by total bills sponsored, was strongly related to Latino interest bill sponsorship, as expected. Two items worthy of note from the analysis of sponsorship during the 110th Congress are that Border State representatives sponsored more symbolic Latino interest bills than their colleagues, and that black population size was positively related to sponsorship of substantive Latino interest bills, but not symbolic Latino interest bills. With regard to the former, I speculate that some border state representatives - perhaps those in politically precarious positions - saw symbolic bills as a good way to reach out to Latinos without wading into controversial policy territory during a period of electoral upheaval. The fact that black constituencies appear related to the sponsorship of Latino interest bills in substantive, but not symbolic ways is more straightforwardly interpreted. Representatives of black and Latino constituencies respond to many similar substantive socio-economic interests and concerns.

I calculated the estimated differences in the numbers of Latino interest bills sponsored by Latino and non-Latino representatives in relation to varying Latino population sizes in order to illustrate the effect of descriptive representation more concretely. Given a congressional district that was 40 percent Latino and holding other variables at their means, Latino representatives were predicted to sponsor 1.17 Latino interest bills during the 109th Congress and 1.03 Latino interest bills during the 110th Congress. Similarly situated non-Latino representatives were predicted to sponsor only .57 Latino interest bills during the 109th Congress and .32 Latino interest bills during the 110th Congress. 
The estimated gap in sponsorship patterns widened substantively among Latino and non-Latino representatives who served larger Latino constituencies. Given a congressional district that was 60 percent Latino and holding other variables at their means (more than 60 percent of Latino representatives served Latino constituencies at least this large during both congresses), Latino representatives were estimated to sponsor 2.27 Latino interest bills during the 109th Congress and 1.7 Latino interest bills during the 110th Congress. Similarly situated non-Latino representatives (only one non-Latino representative served such a large Latino constituency during these congresses) were estimated to sponsor 1.17 Latino interest bills during the 109th Congress and .56 Latino interest bills during the 110th Congress.

While the raw numbers of bills presented here appear small, they are important given that Latino representatives hail almost exclusively from heavily Latino districts. Most Latino representatives come from districts that are more than 60 percent Latino, and would have been expected to sponsor multiple pieces of Latino interest legislation during either congress analyzed here. Only non-Latino representatives with very large Latino constituencies - a handful of legislators - would reasonably have been expected to sponsor even one Latino interest bill during either congress. The evidence presented here clearly demonstrates that Latino representatives, on average, took disproportionately greater action with regard to sponsorship of Latino interest bills during both Republican and Democratic Congresses.

Table 4 shows the results of analyses that examine bill sponsors who served full terms in both the 109th and 110th Congress. As expected, majority party status had a positive effect on overall sponsorship behaviors. Both Democrats and Republicans sponsored more bills when their parties were in the majority. And while Latino representatives sponsored fewer bills than non-Latino representatives across these congresses, as they did during each individual session, majority party status increased the sponsorship productivity of Latino representatives significantly. Given a Latino population of 50 percent and holding other variables at their means, majority status boosted the overall sponsorship productivity of the average Latino representative by more than seven bills.

My analysis of Latino interest bill sponsorship across congresses reveals that party status was not a factor in determining this type of sponsorship generally, nor did party status impact the sponsorship behaviors of Latino representatives specifically. In other words, party status was neither a major determinant nor deterrent of Latino interest bill sponsorship by Latino (or non-Latino) representatives. Consistent with their behaviors during the 109th and 110th Congresses, Latino representatives sponsored significantly more Latino interest bills than their non-Latino colleagues across congresses. Latino constituency size also positively and significantly predicted Latino 


\section{Table 4. Bill Sponsorship Patterns, 109th and 110th Congresses Negative Binomial Regression, Counts of Bills}

\begin{tabular}{|c|c|c|c|c|}
\hline & $\begin{array}{c}\text { Total } \\
\text { Bills } \\
\text { Sponsored }\end{array}$ & $\begin{array}{l}\text { Latino } \\
\text { Interest } \\
\text { Bills }\end{array}$ & $\begin{array}{c}\text { Substantive } \\
\text { Latino } \\
\text { Interest }\end{array}$ & $\begin{array}{l}\text { Symbolic } \\
\text { Latino } \\
\text { Interest }\end{array}$ \\
\hline Latino Representative & $\begin{array}{l}-0.729 * * * \\
(0.181)\end{array}$ & $\begin{array}{l}1.131^{* * * *} \\
(0.355)\end{array}$ & $\begin{array}{l}0.952 * * \\
(0.390)\end{array}$ & $\begin{array}{l}1.529 * * \\
(0.614)\end{array}$ \\
\hline Majority Party & $\begin{array}{l}0.243 * * * \\
(0.034)\end{array}$ & $\begin{array}{c}0.068 \\
(0.155)\end{array}$ & $\begin{array}{c}0.122 \\
(0.170)\end{array}$ & $\begin{array}{l}-0.241 \\
(0.378)\end{array}$ \\
\hline Latino Rep.*Majority & $\begin{array}{l}0.242^{* *} \\
(0.112)\end{array}$ & $\begin{array}{l}-0.275 \\
(0.220)\end{array}$ & $\begin{array}{l}-0.275 \\
(0.271)\end{array}$ & $\begin{array}{l}-0.083 \\
(0.451)\end{array}$ \\
\hline Democrat & $\begin{array}{c}0.108 \\
(0.207)\end{array}$ & $\begin{array}{c}0.101 \\
(0.492)\end{array}$ & $\begin{array}{c}0.261 \\
(0.548)\end{array}$ & $\begin{array}{l}-1.596^{*} \\
(0.881)\end{array}$ \\
\hline Member Conservatism & $\begin{array}{c}0.321 \\
(0.256)\end{array}$ & $\begin{array}{l}-0.240 \\
(0.545)\end{array}$ & $\begin{array}{l}-0.118 \\
(0.599)\end{array}$ & $\begin{array}{l}-1.302 \\
(0.941)\end{array}$ \\
\hline Total Bills sponsored & - & $\begin{array}{l}0.027^{* * * *} \\
(0.004)\end{array}$ & $\begin{array}{l}0.028^{* * * *} \\
(0.004)\end{array}$ & $\begin{array}{l}0.026^{* * * *} \\
(0.010)\end{array}$ \\
\hline Female Representative & $\begin{array}{c}0.148^{*} \\
(0.087)\end{array}$ & $\begin{array}{l}-0.007 \\
(0.220)\end{array}$ & $\begin{array}{l}-0.007 \\
(0.229)\end{array}$ & $\begin{array}{l}-0.235 \\
(0.416)\end{array}$ \\
\hline Minority Representative & $\begin{array}{c}0.100 \\
(0.147)\end{array}$ & $\begin{array}{c}0.823 \\
(0.370)\end{array}$ & $\begin{array}{c}0.844^{*} \\
(0.437)\end{array}$ & $\begin{array}{c}1.009 \\
(0.623)\end{array}$ \\
\hline Latino Population & $\begin{array}{c}0.598 * \\
(0.338)\end{array}$ & $\begin{array}{l}2.871 * * * \\
(0.694)\end{array}$ & $\begin{array}{l}2.807 * * * \\
(0.801)\end{array}$ & $\begin{array}{l}4.088 * * * \\
(1.043)\end{array}$ \\
\hline Black Population & $\begin{array}{l}-0.731 * * \\
(0.291)\end{array}$ & $\begin{array}{c}0.089 \\
(0.935)\end{array}$ & $\begin{array}{l}-0.111 \\
(1.063)\end{array}$ & $\begin{array}{c}0.452 \\
(1.692)\end{array}$ \\
\hline Constituency Conservatism & $\begin{array}{l}-0.016^{* * * *} \\
(0.004)\end{array}$ & $\begin{array}{l}-0.021 * * * \\
(0.009)\end{array}$ & $\begin{array}{l}-0.022 * * \\
(0.010)\end{array}$ & $\begin{array}{l}-0.030^{*} \\
(0.016)\end{array}$ \\
\hline Border State District & $\begin{array}{l}-0.039 \\
(0.095)\end{array}$ & $\begin{array}{c}0.267 \\
(0.224)\end{array}$ & $\begin{array}{c}0.052 \\
(0.267)\end{array}$ & $\begin{array}{l}1.454 * * * \\
(0.390)\end{array}$ \\
\hline Constant & $\begin{array}{l}3.698^{* * * *} \\
(0.214)\end{array}$ & $\begin{array}{l}-1.756^{* * * *} \\
(0.517)\end{array}$ & $\begin{array}{l}-1.887^{* * * *} \\
(0.588)\end{array}$ & $\begin{array}{l}-3.337 * * * \\
(1.076)\end{array}$ \\
\hline lnalpha & $\begin{array}{l}-1.112 \\
(0.066)\end{array}$ & $\begin{array}{l}-0.452 \\
(0.301)\end{array}$ & $\begin{array}{l}-0.164 \\
(0.266)\end{array}$ & $\begin{array}{l}-0.110 \\
(0.422)\end{array}$ \\
\hline alpha & $\begin{array}{c}0.329 \\
(0.022)\end{array}$ & $\begin{array}{c}0.636 \\
(0.192)\end{array}$ & $\begin{array}{c}0.849 \\
(0.225)\end{array}$ & $\begin{array}{c}0.896 \\
(0.378)\end{array}$ \\
\hline Number of Observations & 736 & 736 & 736 & 736 \\
\hline Wald Chi-Square(12) & 134.850 & 352.810 & 277.86 & 141.59 \\
\hline Probability $>$ Chi-Square & 0.000 & 0.000 & 0 & 0 \\
\hline Log Pseudolikelihood & -2868.969 & -516.841 & -478.9769 & -148.51098 \\
\hline
\end{tabular}


interest sponsorship across congresses, suggesting the presence of general policy responsiveness to Latino constituencies on the part of representatives in the sample. Finally, constituency conservatism was significantly and negatively related to Latino interest bill sponsorship across congresses.

Results from analyses of substantive and symbolic Latino interest bill sponsorship across congresses were largely similar to those analyzing sponsorship of all Latino interest bills, with a couple of noteworthy exceptions. First, Democrats sponsored significantly fewer symbolic Latino interest bills, holding other variables constant, suggesting that Republican representatives in the sample were comparatively disposed toward sponsoring such bills. Second, and as was the case during the 110th Congress, representatives from Border States sponsored significantly more symbolic Latino interest bills. It seems plausible that some Republicans saw sponsoring symbolic Latino interest bills as a relatively costless method for reaching out to their Latino constituents. Along similar lines, representatives from Border States may have been comparatively likely to view symbolic Latino interest bills as a relatively non-controversial way to demonstrate responsiveness to a population that is especially politicized in the Southwest United States. Both of these findings suggest, ultimately, that some of the symbolic Latino interest bill sponsorship activity during the period was motivated by electoral impulses in the context of complex and tumultuous electoral climates.

\section{Discussion}

Who represents Latinos in their legislative efforts? What effect does party status have on those efforts? And what can the findings of this analysis tell us about the relationship between descriptive and substantive representation? An obvious place to begin this assessment is with the familiar relationship between representative behavior and constituency interests. The results of this analysis illustrate that U.S. representatives respond to larger Latino constituencies by sponsoring more Latino interest legislation-with both substantive and symbolic content. This is important because it establishes the presence of an electoral connection between this underrepresented population and the legislators by whom Latinos are served (Mayhew 1974). Much as we might expect representatives to respond to issue based constituencies, then, there appears to be a level of congruence or correspondence between the volume of Latino interest in a district and the legislative agendas of representatives (Miller and Stokes 1963). Sponsorship of Latino interest bills contributes to substantive and vital "hard" policy connections (Fenno 2003) between Latino constituencies and their representatives.

Also clear from this analysis is the fact that Latino representatives play a substantial and significant role in representing Latinos in congressional 
legislation. Latino concerns and interests characterized the bills sponsored by Latino representatives during the 109th and 110th Congresses to a much greater extent than they characterized the legislative agendas of non-Latinos. Although Latino representatives made up only about six percent of congressional membership during either congress, they were responsible for at least a third of the Latino interest bills sponsored during each individual congress. Twenty-four Latino representatives (of the 368 who served full terms in each congress) were responsible for 154 of the 415 Latino interest bills (37\%) sponsored by these members across the two congresses. The effort put forth by Latino representatives to represent Latinos in the bills they sponsored indicates something important about their closeness to and comfort with Latinos as a constituency (Fenno 1977, 2003). As an activity that is demanding of representatives' time and efforts, the sponsorship patterns of Latino representatives illustrate the extent to which they prioritize Latino concerns and interests (Hall 1996). The legislative behaviors of Latino representatives underscore a bond with Latino constituencies through a heightened level of activism on their behalf.

Evidence that majority status impacted overall sponsorship patterns of Latino and non-Latinos representatives, but not Latino interest bill sponsorship, suggests a number of important conclusions about the effect of institutional factors on Latino representation. First, while representatives tend to expand their legislative portfolios when in the majority, Latino interest bills do not appear substantially tied to these calculations. The fact that sponsoring Latino interest bills seem based on factors different from those that govern legislative activity more generally suggests motivations that shape this behavior are somewhat unique. Second, and especially given that the overall number of Latino interest bills identified during the Democratically controlled 110th Congress was lower than the number sponsored during the Republican controlled 109th Congress, it appears that Latino interests receive no automatic boost from Democratic agenda setting. While we might speculate that Democratic control would favor initiatives related to Latino interests, given that many Latino interest bills propose programs associated with more liberal priorities, and also given that the vast majority of Latino representatives are Democrats, representatives neither appear to ramp up sponsorship of Latino interest bills during Democratic control, nor curtail such efforts under Republican control. Party control and party status, it would seem, have little to do with efforts to place Latino interests on the policy agenda.

The fact that party status failed to influence Latino interest bill sponsorship among the most active group of sponsors, Latino representatives, arguably underscores the strength of the relationship between descriptive representation and the substantive representation of Latinos in congressional 
legislation. The greater efforts of Latino representatives to represent Latinos in the bills they sponsor appears unmoored from considerations about legislative success that shape sponsorship behaviors more broadly. This suggests a deep commitment to such initiatives, and strengthens notions that experiential connections between these descriptive representatives and their Latino constituents motivate action on behalf of Latinos.

As suggested earlier, institutional factors do not figure into theoretical discussions about the mechanisms by which descriptive representatives enhance substantive representation. The findings presented here help to establish more firmly that the effect of descriptive representation is independent of some important institutional factors that generally shape legislative behavior. By extension, they also illustrate a portion of the larger role descriptive representation plays in the substantive representation of groups. While a number of scholars have questioned the importance of descriptive representatives to group representation, relative to the importance of representatives who are ideologically congruent with group interests, the evidence presented here qualifies such arguments (Swain 1993; Lublin 1997). Larger numbers of descriptive representatives could, paradoxically, be associated with less aggregate-level roll call voting congruence with preferences of groups like Latinos, and diminish Latino representation along an important substantive dimension (Lublin 1997). But evidence presented here suggests that descriptive representatives make contributions to the congressional policy agenda that enhance the representation of group interests in other important ways. Ultimately, these apparently contradictory conclusions likely emphasize substantive differences in the indicators by which substantive representation is measured to a greater extent than they reflect true discord among empirical studies. What appears clear is that descriptive representatives more actively place Latino concerns, priorities, and interests on the congressional policy agenda, enhancing Latino representation. This evidence strengthens arguments that descriptive representation shapes Latino representation in substantial and robust ways.

\section{NOTES}

${ }^{1}$ In order to identify Latino representatives for this study I adopted the inclusive rule used by the Congressional Hispanic Caucus to determine its membership. The CHC considers representatives with both Spanish and Portuguese linguistic heritage to be Latino representatives. Twenty-seven Latino representatives served during the 109th Congress (21 Democrats and 6 Republicans). Twenty-six Latino representatives served during the 110th Congress (22 Democrats and 4 Republicans). Twenty-four Latino representatives (20 Democrats and 4 Republicans) served full terms in both the 109th and 110th Congresses.

${ }^{2}$ Population data based on the 2000 U.S. Census. 
${ }^{3}$ The ideological measure used is the first dimension of the DW-NOMINATE data developed by Poole and Rosenthal (1997) for the 109th and 110th Congresses.

${ }^{4}$ Presidential vote for George W. Bush in 2004 is used to indicate constituency conservatism.

${ }^{5}$ Because Latino interest bill sponsorship is heavily skewed toward zero, the most commonly used distribution for measuring count outcomes, the Poisson distribution, is inappropriate for this analysis. An underlying assumption of the Poisson distribution, that the variance=mean within the population, is not met (Long and Freese 2003). Negative binomial regression adjusts for this skew in distributions, and alpha tests confirm that due to over-dispersion, it is a more appropriate model for this analysis.

\section{REFERENCES}

Bratton, Kathleen A. 2006. The Behavior and Success of Latino State Legislators: Evidence from the States. Social Science Quarterly 87:1136-1157.

Canon, David T. 1999. Race, Redistricting and Representation. Chicago: University of Chicago Press.

Casellas, Jason Paul. 2007. Latino Representation in Congress: To What Extent Are Latinos Substantively Represented. In Latino Politics: Identity, Mobilization and Representation, eds. Rodolfo Espino, David Leal, and Kenneth J. Meier. Charlottesville: University of Virginia.

Eulau, Heinz, and Paul D. Karps. 1977. The Puzzle of Representation: Specifying Components of Responsiveness. Legislative Studies Quarterly 2:233-254.

Frantzich, Stephen. 1979. Who Makes Our Laws? The Legislative Effectiveness of Members of the U.S. Congress. Legislative Studies Quarterly 4:409-428.

Fenno, Richard F. 1977. U.S. House Members in Their Constituencies: An Exploration. American Political Science Review 71:883-917.

Fenno, Richard. 2003. Going Home, Black Representatives and their Constituents. Chicago: University of Chicago Press.

Hall, Richard. 1996. Participation in Congress. New Haven, CT: Yale University.

Hero, Rodney E., and Caroline J. Tolbert. 1995. Latinos and Substantive Representation in the U.S. House of Representatives: Direct, Indirect, or Nonexistent? American Journal of Political Science 39:640-652.

Huerta, Juan Carlos, and Adolfo Santos. 2006. Latino Representation in the U.S. Congress: How Much and by Whom? American Review of Politics 27:115-128.

Kerr, Brinck, and Will Miller. 1997. Latino Representation, It's Direct and Indirect. American Journal of Political Science 41:1066-1077.

Knoll, Benjamin R. 2009. ¿Amigo de la Raza? Reexamining Determinants of Latino Support in the U.S. Congress. Social Science Quarterly 90:179-195.

Long, J. Scott, and Jeremy Freese. 2003. Regression Models for Categorical and Dependent Variables Using STATA. College Station, TX: STATA Press.

Lublin, David. 1997. The Paradox of Representation. Princeton, NJ: Princeton University Press.

Mansbridge, Jane. 1999. Should Blacks Represent Blacks and Women Represent Women? A Contingent 'Yes.' Journal of Politics 61:628-657.

Mayhew, David. 1974. Congress: The Electoral Connection. New Haven, CT: Yale University. 
Menifield, Charles E., ed. 2001. Representation of Minority Groups in the U.S. Lanham, MD: Austin and Winfield Publishers.

Miller, Warren E., and Donald E. Stokes. 1963. Constituency Influence in Congress. American Political Science Review 57:45-56.

Meier, Kenneth. 1993. Latinos and Representative Bureaucracy: Testing Thompson and Henderson Hypotheses. Journal of Public Administration Research and Theory 3:393-414.

Moore, Michael K., and Sue Thomas. 1991. Explaining Legislative Success in the U.S. Senate: The Role of Majority and Minority Parties. Western Political Quarterly 44:959-970.

Pitkin, Hanna Fenichel. 1967. The Concept of Representation. Berkeley: University of California Press.

Poole, Keith T., and Howard Rosenthal. 1997. Congress: A Political-Economic History of Roll Call Voting. New York: Oxford University Press.

Rocca, Michael, and Gabriel R. Sanchez. 2008 The Effect of Race and Ethnicity on Bill Sponsorship and Cosponsorship in Congress. American Politics Research 36:1.

Rosenthal, Cindy Simon, ed. 2002. Women Transforming Congress. Norman: University of Oklahoma.

Ross, Ashley D., Stella M. Rouse, and Kathleen A. Bratton. 2010. Latino Representation and Education: Pathways to Latino Student Performance. State Politics and Policy Quarterly 10:69-95.

Santos, Adolfo, and Juan Huerta. 2001. An Analysis of Descriptive and Substantive Latino Representation in Congress. Pp. 57-76 in Representation of Minority Groups in the U.S., ed. Charles E. Menifield. Lanham, MD: Austin and Winfield Publishers.

Swain, Carol. 1993. Black Faces Black Interests. Cambridge, MA: Harvard University Press.

Swers, Michele L. 2002. The Difference Women Make. Chicago: University of Chicago Press.

Tamerius, Karen. 1995. Sex, Gender, and Leadership in the Representation of Women. In Gender Power, Leadership and Governance, eds. Georgia Duerst-Lahti and Rita Mae Kelly. Ann Arbor: University of Michigan Press.

Theriault, Sean M. 2008. Party Polarization in Congress. New York: Cambridge University.

Williams, Melissa. 1998. Voice Trust and Memory. Princeton, NJ: Princeton University.

Wilson, Walter. 2009. Latino Representation on Congressional Websites. Legislative Studies Quarterly 34:427-448.

Welch, Susan, and John R. Hibbing. 1984. Hispanic Representation in the U.S. Congress. Legislative Studies Quarterly 10:125-134.

Wolbrecht, Christina. 2002. Female Legislators and the Women's Rights Agenda: From Feminine Mystique to Feminist Era. In Women Transforming Congress, ed. Cindy Simon Rosenthal. Norman: University of Oklahoma.

Young, Iris Marion. 2000. Inclusion and Democracy. New York: Oxford University Press. 